Research Article

Open Access

\title{
A Theoretical Model for Ore Mining Waste Management with regard to Pollution of Food Webs in Water Bodies
}

\author{
Jan Stenis $^{1 \star}$, and William Hogland ${ }^{2}$ \\ ${ }^{1}$ LundaHydro AB, Vårlöksvägen 4, Borgholm, Sweden \\ ${ }^{2}$ Department of Biology and Environmental Science, Linnaeus University, Kalmar, Sweden
}

\section{Article Info}

*Corresponding author:
Jan Stenis
LundaHydro AB
Vårlöksvägen 4
Borgholm
Sweden
E-mail: jan.stenis@hotmail.com

Received: January 28, 2019

Accepted: March 20, 2019

Published: March 27, 2019

Citation: Stenis J, Hogland W. A Theoretical Model for Ore Mining Waste Management with regard to Pollution of Food Webs in Water Bodies. Madridge J Agric Environ Sci. 2019; 2(1): 48-50.

doi: 10.18689/mjaes-1000109

Copyright: ( 2019 The Author(s). This work is licensed under a Creative Commons Attribution 4.0 International License, which permits unrestricted use, distribution, and reproduction in any medium, provided the original work is properly cited.

Published by Madridge Publishers

\begin{abstract}
Dam disasters occur sometimes frequently around the world as they did recently in 2015 and 2019 in Minas Gerais, Brazil. As a result, hundreds of families were displaced, and many cities suffered from water shortages. The study aimed to reduce ore mining waste pollutions in rivers and ocean currents and therefore mitigate their impact on the food webs. A model based on the equality principle named EUROPE (Efficient Use of Resources for Optimal Production Economy) was used to estimate shadow costs of economic systems. It was applied to ore mining wastes management in order to mitigate their negative impact on rivers and oceans. As a result, it gave a comprehensive picture of that management system in economic, technical as well as environmental terms.
\end{abstract}

Keywords: Modelling; Dam disaster; Environmental degradation; Soil pollution; Water shortage.

\section{Introduction}

A food web is a natural interconnection of food chains and a graphical representation of what-eats-what in an ecological community such as rivers and oceans [1]. On November 5, 2015, an iron ore tailing dam in Mariana (Brazil) suffered a catastrophic failure [2,3]. On January 25, 2019, another Brazilian dam collapsed in Brumadinho at Belo Horizonte.

The objective of this paper is to prevent and reduce damage resulting from such disasters. The tool is the Efficient Use of Resources for Optimal Production Economy (EUROPE) model [4-6] which was adapted to ore mining wastes in rivers and ocean currents for better protection of food webs regarding these ecosystems.

The main hypothesis in this paper is that pollution by ore mining waste in rivers and ocean currents can be reduced by applying the EUROPE model [4-6]. The main goal is to make the negative impact on food webs less significant by facilitating model daily use by managers and operators. This study is a contribution to improve the living conditions for communities located near mines. The research gap that this study fills is the need to develop new economic instruments to manage ore mining wastes from industrial schemes. The research questions to be addressed are the following: (i) How can we use the model to improve the resource efficiency of production units, such as ore mines? (ii) How can a versatile economic tool be developed for this purpose? (iii) Who are the other potential end users apart from mining companies?

Generally, we explore how the EUROPE model can theoretically be applied to promote economic, environmental and technological development of ore mining, and 
who would benefit from such endeavour. This research provides a better understanding of how natural resource management could be facilitated through the application of an economic instrument for reducing ore mining spillage.

\section{Methodology}

\section{General theory of the EUROPE model}

$\mathrm{PF}=A /(B+C)$

$\mathrm{SC}=$ corporate-internal shadow cost additionally allocated to $A=\mathrm{PF} * \mathrm{TC}$

$\mathrm{TC}=$ Total Costs $=$ Fixed Costs + Variable Costs $=$ FC + VC

$\mathrm{SC}=(A *(\mathrm{FC}+\mathrm{VC})) /(B+\mathrm{C})$

where: PF is the Proportionality Factor, $A$ is the quantity of the residuals from a certain resource produced that are to be optimized, $B$ is the quantity of the regular resource output, $C$ is the sum of the quantities of the fractions stemming from 'the black box' of the studied system, $i=1,2 \ldots n$ in order of estimated, and descending economic and/or environmental relevance. Unit: kg, litres, Joule, $€, \$$, $£$, etc.

Equation (1) represents the economic implications of the equality principle regarding the model. An administrative unit and system limit must be defined when (4) is applied.

\section{Theory for reduction of ore mining pollution}

Equation (4) gives:

Food web care shadow cost $=$ FOODWEBCAST tot $=$

$$
=\Sigma\left[A_{i} /\left(B_{i}+C_{i}\right)\right] * \mathrm{TC}_{i}
$$

$i=1,2, \ldots$, river and/or ocean current $j$

where: FOODWEBCAST ${ }_{\text {tot }}=$ total shadow cost of the $n$ rivers and/or ocean currents being polluted

$A_{i}=$ quantity of the unwanted river or ocean current nutrients=the 'bad'

$B_{i}=$ quantity of the important nutrients in a river or the ocean current $i$

$C_{i}=$ quantity of all regular river or ocean current nutrients flows

$\mathrm{TC}_{i}=$ Total societal cost of river or ocean current $i$ being polluted by $A_{i}$

$j=1,2, \ldots, n$ in a suitable and defined production or administrative unit during a certain time.

Sort: $k g, €, \$, £$ or $\mathrm{R} \$$ etcetera.

FOODWEBCAST tot is inserted into the budget or accounts of the relevant economic entity, for example, the South American trade bloc Mercosur [7] to induce an economic incentive to maintain $A_{i}$ and hence preserve life on planet Earth by increasing the PSBR.

The higher the quantity of the harmful nutrients in the river or ocean current $i$, the more of FOODWEBCAST ${ }_{\text {tot }}$ is allocated to the polluting trade block in question. This enforces economic incentives to produce more lowconcentrated ore that is still of commercial interest. Therefore, FOODWEBCAST is considered as an economic instrument to promote life.

The development of viable technological methods for excavation of rocks with a lower concentration of pollutants is promoted. This reduces the shadow costs or shadow prices [8] allocated to trade blocks that perform ore mining at different concentrations of pollutants.

The methodology promotes ore mining with less concentration of pollutants due to economic incentives.

\section{Results and Discussion}

\section{River case study}

$A_{\text {river }}=2 \mathrm{mg} \mathrm{Mg} / \mathrm{l}[9], B_{\text {river }}+C_{\text {river }}=0,1 \mathrm{mg} \mathrm{P} / \mathrm{l}+1 \mathrm{mg} \mathrm{N} / \mathrm{l}$ [10], $\mathrm{TC}_{\text {river }}=\mathrm{USD} 5.1$ billion [11], Equation (5) gives:

FOODWEBCAST $_{\text {river }}=$ total shadow cost of the studied river and ocean currents being polluted $=[2 \mathrm{mg} /(0.1 \mathrm{mg}+1 \mathrm{mg})]$ * USD 5.1 billion=USD 9.3 billion

USD 9 billion is added to the public finances for the current trade block as a shadow cost.

\section{Analysis}

The equation (5) enables estimation of shadow costs supposed to be inserted in the economic system of larger institutions. The model allows managers to have a comprehensive picture of the economic, technical and environmental situation.

The case study findings show model usefulness for addressing environmental issues such as food webs in water bodies. Its accuracy was tested [12] using real world-values.

\section{The EUROPE model key terms}

This study is a contribution to improvement of living conditions of communities located in mine surroundings. The research question lies on how we could use the model to improve the resource efficiency of production units. The model could therefore be important for population living in the vicinity of major ore mines. Other potential model end users, apart from mining companies, could be environmental protection agencies.

The major benefit from the model lies in the reduction of shadow costs $(\mathrm{SC})$ related to mining waste management. This positively impacts on ore mining performance in technical, economic and environmental terms.

As a key indicator, SC shows over time changes in effective use of mining resources. If SC increases, this calls for actions from the company in terms of implementation of technical measures required to improve company performance [13]. The SC is a sort of warning signal indicating how the toxicity of mining wastes may change over time. Studying the SC helps determine the magnitude of measures required to be implemented. For example, a high SC values tell that major changes are required. Changes in SC point at how effective 
mining waste management could build up soil nutrients and lower pollutants in rivers or ocean currents. The relationship is linear between $A$ and FOODWEBCAST.

The SC in the model does not show the value of mining equipment, nor does it consider how much money the company has on its bank account [13]. However, SC indicates how efficiently is the company using its resources to produce non-toxic compounds and allowing mining companies to evaluate its use of resources over time.

The usefulness of ore mining wastes could be optimized by using the model as an economic tool to prevent future disasters like the one occurred in Mariana (Brazil) in 2015.

Investments in ore production machinery decrease the toxicity of mining wastes with a decrease in harmful nutrient levels over time. If SC increases, correcting measures might be taken to preserve food webs. The SC provides a key indicator which summarizes the economic, environmental and technological performance of most mining companies and other industries.

\section{Conclusion}

The EUROPE model can be applied to mining wastes management to reduce their effects on food webs and mitigate their negative impact on rivers and oceans. It is useful for environmental issues in general and particularly for maintenance and reinforcement of food webs in water bodies.

The approach novelty lies in the use of shadow costs to create economic incentives for improvement of mining waste management. Further research could develop mathematical models that better describe food web pollution issues such as gaseous pollutions around mines.

\section{References}

1. Wikipedia. Food web. 2018.

2. Wikipedia. Mariana, Minas Gerais. 2018.

3. Wikipedia. Bento Rodrigues dam disaster. 2018.

4. Stenis J, Hogland W. The polluter-pays principle and its environmental consequences for industrial waste management. Environment, Development and Sustainability. 2002; 4(4): 361-369.

5. Stenis J, Hogland W. Optimization of mining by application of the equality principle. Resources Policy. 2011; 36(3): 285-292.

6. Stenis J, Hogland W. Cost-effectiveness of recycling and recirculation of natural and energy resources based on the equality principle. Environment, Development and Sustainability. 2016; 18(1): 95-109.

7. Mercosur. Statistics. 2018.

8. Your Dictionary. Shadow price. 2018.

9. Potasznik A, Szymczyk S. Magnesium and calcium, concentrations in the surface water and bottom deposits of a river-lake system. Journal of Elementology. 2015; 20(3): 677-692. doi: 10.5601/jelem.2014.19.4.788

10. Wieben $C M$, Baker RJ, Nicholson RS. Nutrient concentrations in surface water and groundwater, and nitrate source identification using stable isotope analysis, in the Barnegat Bay-Little Egg Harbor Watershed, New Jersey, 2010-11. U.S. Geological Survey Scientific Investigations Report 2012-5287. 2013.

11. Sullivan Z. Brazil's Doce River still foul eight months after dam collapse. Deutsche Welle. 2019.

12. Gastel B, Day RA. How to write and publish a scientific paper, 8th Edition. Westport, CT: Greenwood Publishing Group. 2016.

13. Stenis J, Hogland W. Guidelines for practical application of the EUROPE model to improve production units' resource efficiency. The Open Waste Management Journal. 2018; 11(1): 41-49. 